溶出電解質量測定による チャ冬芽の耐凍性評価法の利用

(独) 農業・食品産業技術総合研究機構 野菜茶業研究所* 松永明子

(平成24年11月 5 日受理)

\section{Evaluation Method of Tea-shoot Freezing Resistance by Measuring Electrolyte Leakage}

\author{
Akiko Matsunaga \\ NARO Institute of Vegetable and Tea Science
}

\section{Summary}

To evaluate the freezing resistance of tea shoots during winter and early spring, the electrolyte leakage from tea shoots after cold treatment was assessed by using a conductivity meter. Increase in electric conductivity reflected tissue injury immediately after cold treatment. The variation in electric conductivity indicated the differences in cold resistance among cultivars ('Sofu', 'Yabukita', and 'Fushun'), in addition to the changes in cold resistance from winter to early spring and differences in cold resistance based on whether or not medium pruning treatments were performed.

Key Words : Camellia sinensis, freezing resistance, electrolyte leakage, tea cultivars

キーワード : チャ, 耐凍性評価, 溶出電解質, 導電率

\section{1 諸言}

チャの栽培において, 初冬期の霜害や春先 の冬芽への凍霜害は一番茶の減収や品質低下 を引き起こす ${ }^{1,2)}$ 。凍霜害の回避には, 茶樹 の耐凍性の把握が重要である。これまで, 冬 から春先にかけての冬芽の耐凍性が様々な方 法で評価されているが, 評価に日数を要した り, 評価者により基準が異なるなどの問題が ある ${ }^{3,4)}$ 。そのため簡便で正確な耐凍性の評 価方法, 耐凍性の時期的変化および品種間差 を明らかにすることなどが必要となる。

吉田らが考案した，低温処理後の冬芽を水 に浸漬し，植物組織から溶出する電解質を簡 易型導電率計で計測し耐凍性を評価する方法 は，簡便迅速でかつ耐凍性の違いを客観的な 数值で表すことができる ${ }^{5,6)}$ 。そこで，まず 冬芽への低温処理後の導電率変化と生体染色 法および培養後の萌芽率との比較を行い, 組 織の損傷がどのように評価されるか検討を行 った。さらに初冬期から春先にかけて, 耐凍 性が弱いとされる ‘そうふう’と強い“ふう しゅん’の冬芽の低温処理後の溶出電解質量 の経時的変化の調查を行った。また, ‘やぶ きた’を用いて中切りの有無が耐凍性に及ぼ す影響を溶出電解質量測定により検討し，吉 田らの評価方法が耐凍性の経時的変化や品種 の耐凍性の調査などにどのように利用できる かを検討した。

\section{2 材料および方法}

\section{1 供試材料}

試験は2011年12月から2012年 3 月にかけて 行った。供試材料は, (独) 農研機構 野菜 茶業研究所金谷茶業研究拠点の圃場に定植し た ‘そうふう’（9 年生），“ふうしゅん’（18 年生)および対照品種として“やぶきた’（16 年生）を用いた。‘ふうしゅん’，“やぶきた’

テ428-8501 静岡県島田市金谷猪土居2769 
は2011年 5 月の一番茶後に中切り更新を行っ た。さらに, ‘やぶきた’については隣り合 った中切り更新を行った弶と行っていない畧 のそれぞれから材料を採取し, 中切りの耐凍 性に及ぼす影響を調査した。耐凍性の判定方 法による評価の違いは中切りを行っていない ‘やぶきた’を用いて耐凍性が最も安定して いると考えられる 2 月（2012年 2 月 21 日）に 行った。冬期の耐凍性検定は2011年12月初旬 から 2012 年 3 月下旬まで行い 12 月上旬から 2 月中旬は約 2 週間ごと, 2 月下旬から 3 月下 旬は約 1 週間ごとに行った。上位第 1 葉目の 測芽（第 1 測芽）の付いた枝を，10月中旬に 秋整枝した摘採面から $6 \mathrm{~cm}$ 程度の長さに採 取し, 耐凍性の検定処理を行った（写真 1 )。

\section{2 . 2 低温処理}

天候などの採取条件の違いが耐凍性に及ぼ す影響を緩和するため, 低温処理は中野の方 法に準じて行った ${ }^{3)}$ 。低温処理前に枝条全体 を数分間水道水に浸漬した。その後濡れたま まの枝条を各試験区 5 本ずつ（溶出電解質量 測定による評価と生体染色法および萌芽率と の比較試験については各10本) アルミ箔に包 み, これを恒温インキュベーター（福島工業 株式会社製，FMU-053I）で試験前日より 5 ${ }^{\circ} \mathrm{C}$ で保存した。翌朝, まず, $0{ }^{\circ} \mathrm{C} て ゙ 1$ 時間培 養した後, 処理温度 $\left(5{ }^{\circ} \mathrm{C}\right.$ から $\left.-15^{\circ} \mathrm{C}\right)$ で 2 時間の低温処理を行い, $15^{\circ} \mathrm{C}$ で 1 時間培養し た。その後被害程度を評価するために, 組織 からの溶出電解質量の測定および培養後の芽 の萌芽率の調査を行った。萌芽率の調査は低 温処理後の切り枝を水道水に挿し, 中野の方 法に準じて $25^{\circ} \mathrm{C}, 14$ 時間日長条件で培養し, その後の供試本数に対する萌芽割合を調査し た ${ }^{3)}$ 。

\section{3 溶出電解質量の測定}

冬芽からの溶出電解質量の測定は吉田らの 方法に準じて行った ${ }^{6)}$ 。第 1 側芽をメスで切
断して枝から採取し，これらを秤量後に，1 芽ずつ48ウェルマイクロプレートに入れ, 蒸 留水を加え緩やかに振とうさせた。ただし, 2012年 1 月 6 日までの調査では, 自重の 20 倍 量, それ以降では一律500uL加え, 測定後に 自重の 20 倍量中の導電率変化に換算した。溶 出電解質量は携帯型導電率計 (HORIBA製, B-173) で導電率 $(\Delta \mathrm{s} / \mathrm{cm})$ を測定し, これ を 0 時間の值とした。測定後, $25^{\circ} \mathrm{C}$ の恒温槽 で 2 時間培養し, 振とう後導電率の測定によ り導電率化を算出し, 冬芽からの溶出電解質 量とした。

\section{4 生体染色法}

導電率測定後直ちに芽の変色程度の観察を 行った。芽をプレートから取り出して, 安全 カミソリで縦に半分に切断し, 死んだ細胞 を $0.5 \%$ エバンスブルー溶液で 3 分間染色後, 蒸留水で洗浄し, 実体顕微鏡を用いて断面を 観察した。エバンスブルーの染色程度により 被害の程度を 3 (強被害), 2 (中被害), 1 (弱被害)，０（無被害）の4段階で評価した (写真 2 )。

\section{3 結果および考察}

\section{1 気温変化}

2011年11月から2012年 3 月の金谷茶業研究 拠点における気温の推移を図 1 に示した。日 平均気温は 2 月 2 日に最も低く $-1.6^{\circ} \mathrm{C}$ を記録 し, 最低極温は 2 月 19 日の $-6.5^{\circ} \mathrm{C}$ であった。

\section{2 芽重の変化}

試験に用いた第 1 側芽の重量は“そうふう’ は12月から 1 月中旬までは $17 \mathrm{mg}$ から $24 \mathrm{mg}$ まで 増加し, その後 2 月中旬にかけて 12 月初旬と 同程度まで減少し, その後は段階的に増加し た。 ‘やぶきた’，“やぶきた’（中切り）, ‘ふ うしゅん’は12月から 2 月中旬までは明確な 変化はなく, 2 月中旬以降は徐々に増加した。 品種間の比較では，“そうふう'と“やぶきた’ 


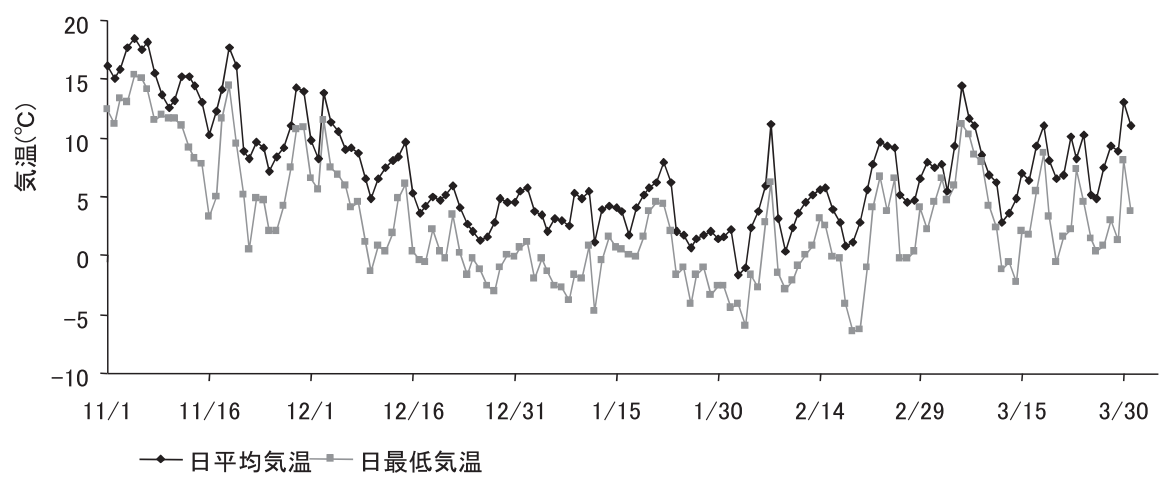

図 1 金谷茶業研究拠点における気温の推移

1 ） 2011年11月 1 日から 3 月31日までの金谷茶業研究拠点気象観測装置のデータ。

(中切り)の重量は, ‘ふうしゅん’と ‘やぶ きた’より重い傾向があった（図 2 )。

3. 3 耐凍性の判定方法による評価の違い 低温処理後の溶出電解質量と処理直後の工
バンスブルー生体染色による組織の観察での 被害程度のグレード分け, 並びに切り枝を $25^{\circ} \mathrm{C} 14$ 時間日長で処理した時の萌芽率を比較 した (表 1 )。溶出電解質量を示す導電率は $-11^{\circ} \mathrm{C}$ 処理で值が大きくなり始め, $-12.5^{\circ} \mathrm{C}$,

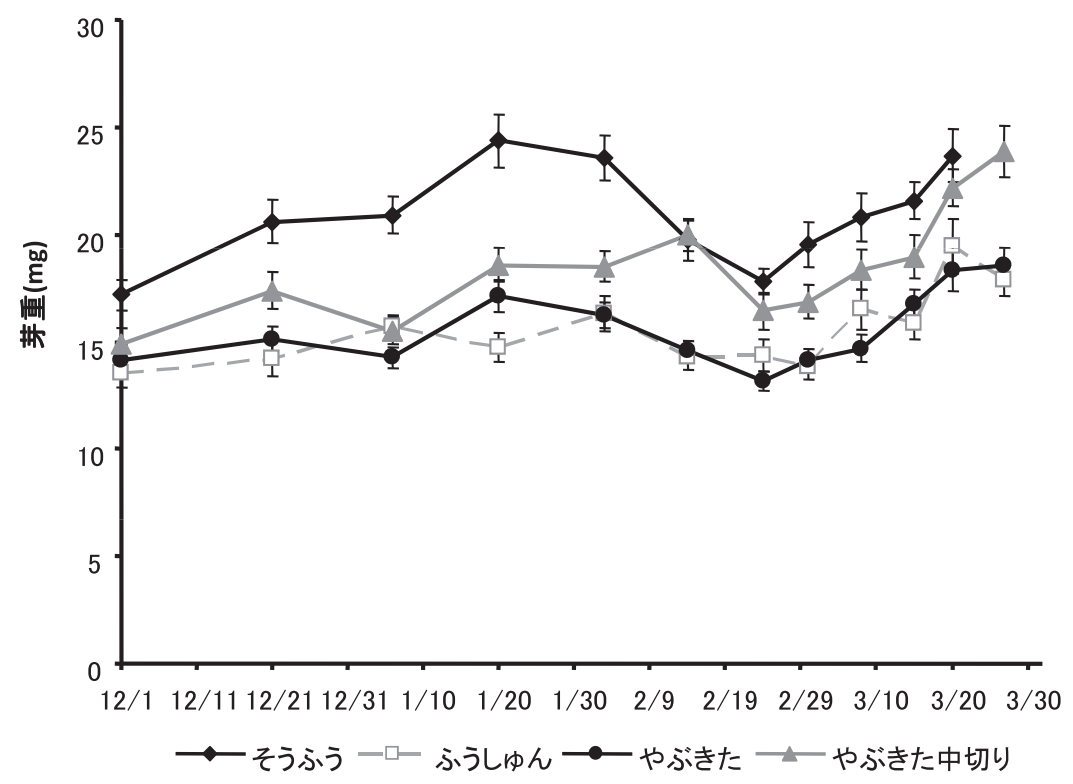

図 2 冬芽の重量変化

1) 試験 は2011年12月 1 日, 21日、2012年 1 月 6 日, 20日, 2 月 3 日, 14日, 24日、 3 月 1 日、 8 日、15日、20 日に行った。

2 ）芽重は溶出電解質量測定に用いた第一側芽の重量。

3） $\mathrm{n}=25$ 。ただし 12 月 1 日は $\mathrm{n}=20,3$ 月15日のとそうふう’と 3 月 20 日、20日はn $=15$ 。

4) 土標準誤差 
表 1 ‘やぶきた’ 冬芽の低温処理の場合の異なる耐凍性判定手法による調査結果の比較

\begin{tabular}{|c|c|c|c|}
\hline $\begin{array}{c}\text { 処理温度 }{ }^{1)} \\
\left({ }^{\circ} \mathrm{C}\right)\end{array}$ & $\begin{array}{c}\text { 溶出電解質測定 } \\
\left.\text { 導電率変化 }^{2}\right) \\
(\Delta \mu \mathrm{s} / \mathrm{cm} / 2 \mathrm{~h})\end{array}$ & $\begin{array}{c}\text { 生体染色による } \\
\text { グレード分け } \\
\text { 被害程度 }^{3)}\end{array}$ & $\begin{array}{c}\text { 水挿し後の萌芽率 } \\
\text { 萌芽率 }{ }^{4)} \\
(\%)\end{array}$ \\
\hline 5.0 & $16 \pm 1 \mathrm{a}$ & $0.0 \pm 0.0$ & 95 \\
\hline-7.5 & $14 \pm 1 \mathrm{a}$ & $0.1 \pm 0.1$ & 100 \\
\hline-9.0 & $16 \pm 1 \mathrm{a}$ & $0.4 \pm 0.2$ & 95 \\
\hline-10.0 & $16 \pm 1 \mathrm{a}$ & $0.6 \pm 0.2$ & 95 \\
\hline-11.0 & $23 \pm 2 \mathrm{a}$ & $0.8 \pm 0.2$ & 40 \\
\hline-12.5 & $40 \pm 7 b$ & $1.9 \pm 0.1$ & 0 \\
\hline-15.0 & $48 \pm 3 b$ & $2.7 \pm 0.2$ & 0 \\
\hline
\end{tabular}

1 ）試験は2012年 2 月20日から21日にかけて実施した。

2) $\mathrm{n}=10$, 土標準誤差，異なるアルファベットは 1 \% 水準で処理区間内で有意差があることを示す。

3 ）切片が明瞭に観察できた芽のグレードの平均值（3 (強被害), 2 (中被害), 1 (弱被害), 0 (無被害)), $\mathrm{n}=10$ (ただし, $-7.5^{\circ} \mathrm{C},-12.5^{\circ} \mathrm{C}$ 処理は $\left.\mathrm{n}=9\right)$ 。

$4 ） 2012$ 年 2 月 21 日水扦しし, 2012 年 3 月 10 日に萌芽率を調查した $(n=20)$ 。

$-15^{\circ} \mathrm{C}$ 処理で顕著に高くなった。生体染色後 のグレード分けによる被害程度の評価は, $-7.5^{\circ} \mathrm{C}$ から $-11^{\circ} \mathrm{C}$ 処理で被害程度が徐々に大 きくなり, $-12.5^{\circ} \mathrm{C},-15^{\circ} \mathrm{C}$ 処理で強被害であ った。処理後の萌芽率は $-10^{\circ} \mathrm{C}$ 処理で低温処 理の影響が観察され, $-11^{\circ} \mathrm{C}$ 処理で萌芽率は $40 \%$ になり,$-12.5^{\circ} \mathrm{C}$ および $-15^{\circ} \mathrm{C}$ 処理では萌 芽せず枯死した。溶出電解質量と生体染色判 定の評価はほぼ一致しており, 処理直後の被 害程度を導電率変化により把握できることが 吉田らの試験と同様に確認された。また, 溶 出電解質量よりも萌芽率の調查の方が被害程 度が大きく判定されたが, 溶出電解質量の測 定の場合は冬芽の組織損傷のみを測定してい るのに対して, 萌芽率調査の場合は, 枝条や 成葉の被害もその後の萌芽に影響すること, 処理後日数経過と共に組織損傷が拡大するこ となどが考えられる。以上のことから, 溶出 電解質量測定は, 被害直後の組織の損傷程度 を反映し, 他の方法と比べ迅速で客観的な結 果が得られるため, 耐凍性の判定に適すると 考えられた。

3. 5 冬期における低温処理後の溶出電解 質量の経時的変化の品種間差異

低温処理を行った各品種の冬芽からの溶
出電解質量の変化を図 3 に示した。そそうふ う’ の $-12.5^{\circ} \mathrm{C},-15^{\circ} \mathrm{C}$ 処理の溶出電解質量は 全期間を通して值が大きかったが，経時的な 傾向は認められなかった。 $-10^{\circ} \mathrm{C}$ 処理では 12 月 1 日より 12 月 21 日の溶出電解質量が少なく なり，その後 2 月24日までは值は低く推移 したが， 3 月 1 日以降高くなった。 $-7.5^{\circ} \mathrm{C}$ 処 理も冬期は值が低く 3 月 1 日以降上昇した。 $-10^{\circ} \mathrm{C},-7.5^{\circ} \mathrm{C}$ の処理ではいずれも常に $-10^{\circ} \mathrm{C}$ 処理の值のほうが高く推移した。‘そうふう’ は 1 月下旬から 2 月の厳寒期, 圑場での枝条 採取時に, 冬芽への凍霜害の発生が観察され た。明らかに被害のある芽は調査対象としな かったが，野外ですでに低温による損傷を受 けており，それが調査毎の数值のばらつきに つながったと推察した。

‘ふうしゅん’は- $15^{\circ} \mathrm{C}$ と $-10^{\circ} \mathrm{C}$ 処理では, 12 月 1 日から 2 月 3 日にかけて溶出電解質量 が小さくなったが, 2 月14日以降は増大した。 また, 全ての処理温度で 2 月14日以降の溶出 電解質量は増大する傾向であった。処理温度 が低いほど春先の溶出電解質量の増大時期が 早くなり, $-15^{\circ} \mathrm{C}$ 処理では 2 月 14 日, $-12.5^{\circ} \mathrm{C}$, $-10^{\circ} \mathrm{C}$ 処理では3月 8 日以降, $-7.5^{\circ} \mathrm{C}$ 処理では 3 月 15 日以降溶出電解質量の值がそれまでよ り高くなった。 $-12.5^{\circ} \mathrm{C}$ 以下の処理では溶出 
そうふう

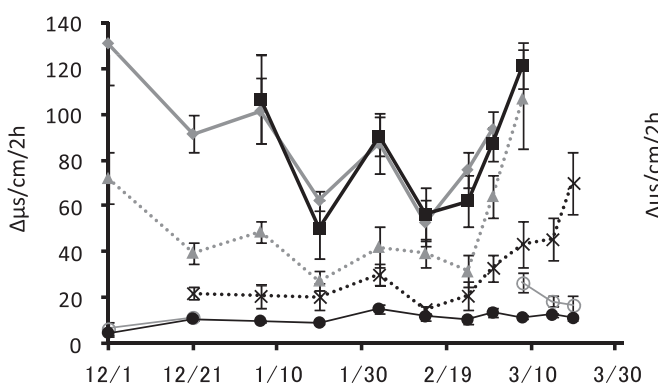

やぶきた

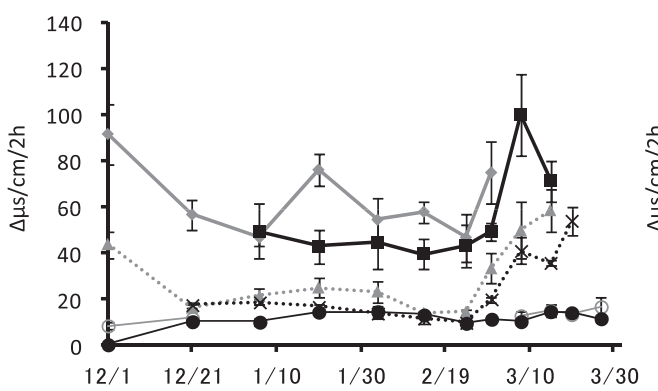

ふうしゅん

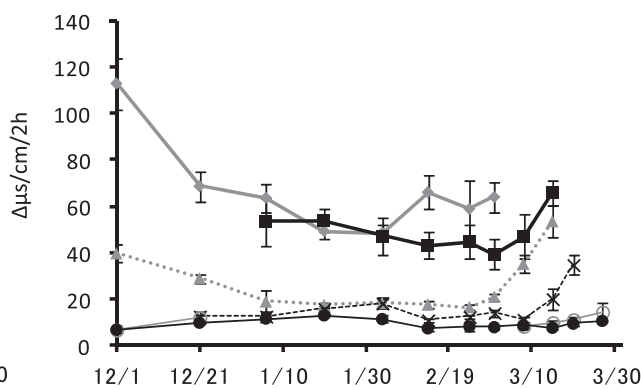

\section{処理温度}

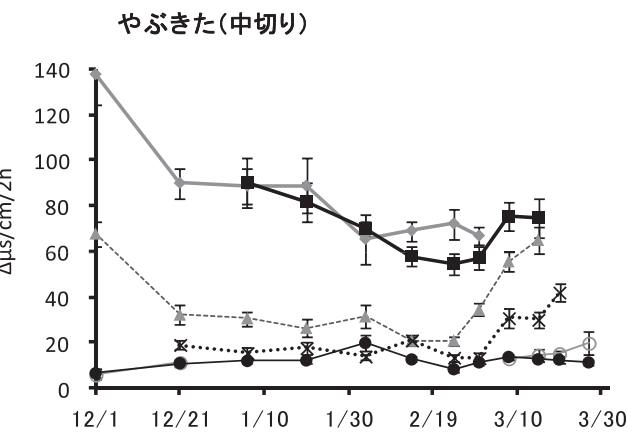

\section{図 3 低温処理による冬芽の溶出電解質量の品種別・時期別推移}

1 ）試験は2011年12月 1 日，21日，2012年 1 月 6 日，20日，2月 3 日，14日，24日，3月 1 日， 8 日，15日，20日 に行った。

2) $\mathrm{n}=5, \quad$ 土標準誤差

電解質量が他の処理温度より大きくなった が, $-10^{\circ} \mathrm{C}$ 以上の処理では, 厳冬期 ( 1 月か ら 2 月）の溶出電解質量は $20 \Delta \mu \mathrm{S} / \mathrm{cm}$ 程度 かそれ以下となった。

‘やぶきた’は- $12.5^{\circ} \mathrm{C}$ 以下の処理では溶出 電解質量の值が高く推移した。 $-10^{\circ} \mathrm{C}$ 以上の 処理では ‘初冬期から厳冬期は ‘京うしゅん” と同程度の溶出電解質量であったが, 春先の 溶出電解質量の増大は ‘やぶきた’の方が早 かった。

これら 3 品種の比較では溶出電解質量から ‘ふうしん’の耐凍性が最も強く‘そうふう’ が弱いことが示された。‘ふうしゅん’は他
の品種より溶出電解質量の值が低く推移し, さらに春先の溶出電解質量の増大も他の品種 より遅かった。このように, 低温処理後の溶 出電解質量を経時的に測定することで品種の 耐凍性の傾向を明らかにすることができると 考えられる。

‘やぶきた’ (中切り) は- $12.5^{\circ} \mathrm{C}$ 以下の処 理では溶出電解質量が多く, 2 月中下旬に最 も值が小さくなった。 $-10^{\circ} \mathrm{C}$ 処理では 12 月中 旬から 2 月下旬まで少なくなったが, $-7.5^{\circ} \mathrm{C}$ の処理では冬期の溶出電解質量は対照の 5 'C処理と同程度であった。‘やぶきた’では 中切り区は中切りをしていない区と比較し, 
$-10^{\circ} \mathrm{C}$ 処理以下では溶出電解質量の值が高く 推移したが， 2 月中下旬はその差が小さくな り, 春先の溶出電解質量の増大には明確な違 いは認められなかった。このことから, 初冬 の耐凍性は中切りにより弱くなるが, 厳冬期 の耐凍性は大きな違いがなく, また, 春先の 耐凍性の低下時期にも大きな違いはないと推 察された。中切りを行うと芽は芽重型となり 秋冬期の芽止まりは緩慢で耐凍性の獲得も遅 れると考えられるが, 溶出電解質量の変化で もこの傾向が示された。このように溶出電解 質量を測定することで栽培管理の違いによる 耐凍性の差も評価できることが示唆された。 試験を行った金谷の気象条件においては, 耐凍性の弱い ‘そうふう’は, 良質な一番茶 を得るには早期の防霜ファンの使用だけでな く, 被覆資材等による防寒対策が必要と考え られる。一方, “ふうしゅん’は初冬期から 耐凍性が強く ‘やぶきた’よりも防霜ファン の使用期間を減らすことができると考えられ るが, これらの防寒や防霜対策時期の判断に 溶出電解質量測定による耐凍性の評価が利用 できると考える。

今回の調査において気温は 1 月下旬から 2 月上旬に最も低く, その時期に耐凍性も最も 強くなり耐凍性の消失は 2 月下旬から観察さ れた。また, 春先の耐凍性の消失は, 芽重の 増加と一致しており, 芽の生長と共に耐凍性 が失われた。耐凍性の強度は, 休眠程度や糖
含量と関連があると考えられるが，本試験の 結果から, 芽重や溶出電解質量からも耐凍性 の獲得, 消失時期や強度が推察できることが 示唆された。

また, 耐凍性品種間差については, これま でも検討が行われているが, 固場観察による 調査が多く, 近年育成された品種を含めて, 同一条件下で客観的な評価法により比較した 例はない。今後, 調查を進め品種普及に役立 てる必要がある。

\section{引用文献}

1）青野英也・笵瀬好充 - 田中静夫 - 菅野 正道 · 加藤正明 (1974) : 茶研報, No.41, 16-36.

2 ) 水上裕造 - 山口優一 (2010) : 茶研報, No.110, 91-94.

3 ) 中野敬之(2002)：日本作物会記事71, 43-49.

4 ）倉貫幸一(1983)：茶研報, No.57, 1-6.

5 ）吉田克志・松尾喜義(2011)：日本作物 学会紀事別号 (講演会要旨. 資料集) No.231, 102-103.

6 ）吉田克志・松尾喜義(2012)：茶研報, No.113, 63-69.

7 ）原田重雄 - 渡辺明 - 中山仰 - 酒井慎介 鳥屋尾忠之 (1958)：東海近畿農業試験場 研究報告茶業部, No.6, 86-124. 
(茶研報114：37～43，2012）

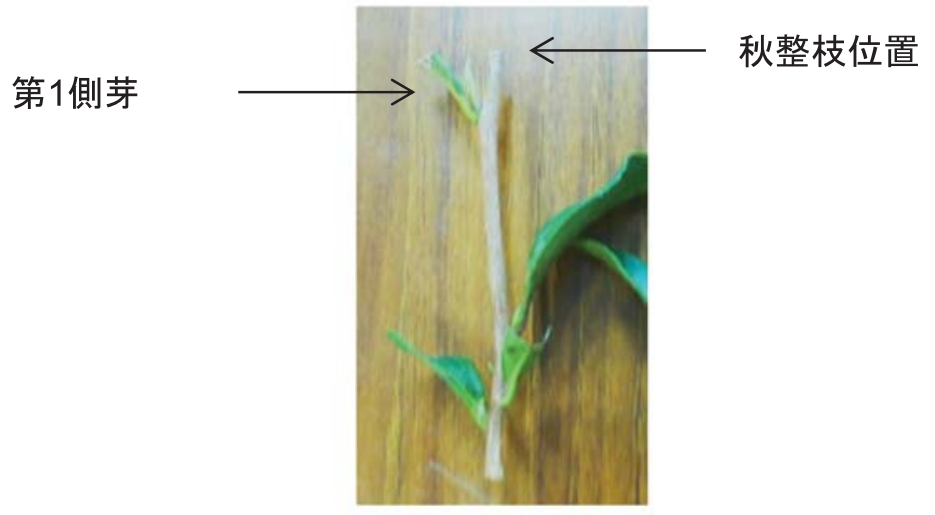

写真 1 低温処理に用いた枝条
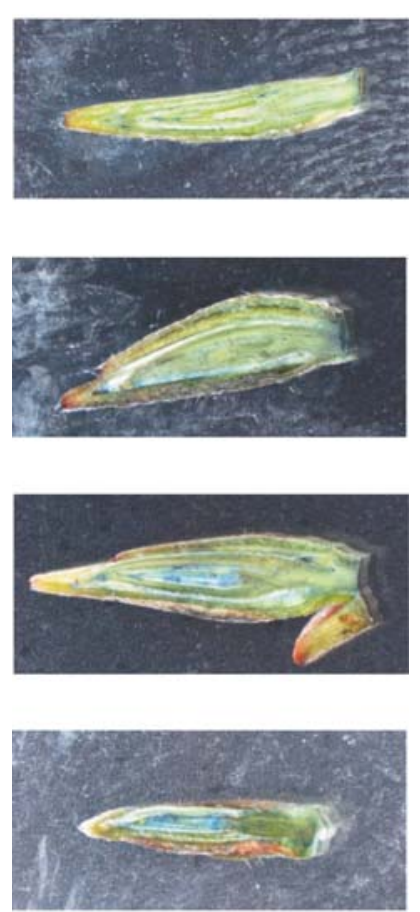

写真 2 エバンスブルー染色による耐凍性被害程度の評価

1 ）溶出電解質量測定後に徒手切片を作成し， $0.1 \%$ エバンスブルーで染色した。

2 ）上から, 被害程度 0 (無被害)，1 (弱被害)，2 (中被害)，3 (强被害) 